\title{
JOURNAL.RU
}

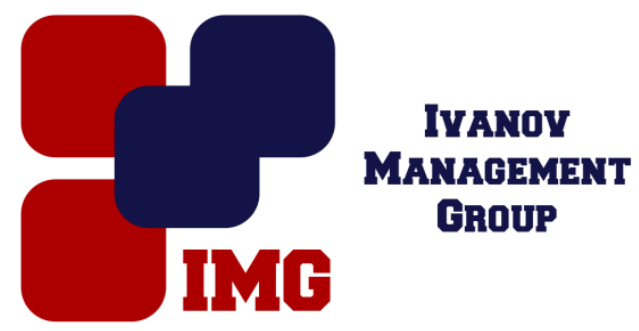

\author{
Скорляков В.В., Бабиев В.Ф., Кещян С.С. \\ ФГБОУ ВО «Ростовский государственный медицинский университет» \\ Минздрава России \\ Ростов-на-Дону, Россия
}

doi: $10.18411 / 1 \mathrm{j}-31-05-2017-43$

idsp 000001:1j-31-05-2017-43

\section{Вегетативная дистониякак предиктор развития хронической ЛОР патологии у больных гастроэзофагеальнойрефлюксной болезнью}

Гастроэзофагеальнаярефлюксная болезнь (ГЭРБ) - это комплекс клинических симптомов и/или морфологических изменений, которые возникают в результате рефлюкса содержимого желудка в пищевод [1]. В настоящее время количество больных с ГЭРБ неуклонно растет $[2,3,4,5]$. В то же время при ГЭРБ воздействие рефлюксата может распространяться и на вышележащие отделы - слизистую ЛОР-органов, вызывая такие заболевания как хронический ларингит, хронический фарингит, синусит, рак гортани и глотки, др. [6, 7, 8]. В связи с этим проявления ГЭРБ принято делить на пищеводные и внепищеводные, при этом последние подразделяются на те, связь которых с рефлюксом установлена, и те, у которых эта связь предполагается $[9,10]$, так как установить такую взаимосвязь бывает достаточно сложно. Доказано, что вегетативная дистония по типу асимпатикотонии усугубляет течение ГЭРБ и может являться предрасполагающим фактором для развития внепищеводных проявлений $[11,12,13]$. В настоящее время в патогенезе развития хронических заболеваний ЛОР-органов большое внимание уделяется функциональному состоянию вегетативной нервной системы $[14,15,16,17]$. Вегетативная нервная система относится к числу интегративных регулирующих систем. Именно ЛОР органы представляют собой периферические отделы тех исполнительных функциональных систем, которые тесно связаны с внешней средой и первыми реагируют на любые ее изменения $[18,19]$. 
Целью работы явилось определение роли вегетативной дистонии в прогнозировании развития ЛОР-проявлений ГЭРБ.

Материалы и методы. Обследовано 104 больных с ГЭРБ в возрасте от 18 до 81 года. Средний возраст больных составил 44,4 $\pm 0,65$ лет. Среди них мужчин было 50 (48 \%), женщин - 54 (52 \%). Критериями включения были больные с ГЭРБ, сопровождающимся присутствием и отсутствием ЛОРпроявлений. Критериями исключения стали аллергические заболевания ЛОР органов, сопутствующие хронические заболевания. Контрольную группу составили 32 практически здоровых человека в возрасте от 20 до 32 лет. По наличию ЛОР-проявлений ГЭРБ больные были распределены на 2 группы. 1-я группа - больные с хроническим фарингитом, хроническим ларингитом, хроническим риносинуситом на фоне ГЭРБ. 2-я группа - больные без патологии ЛОР-органов на фоне ГЭРБ. Всем больным проведено полное клиническое обследование, включающее сбор жалоб и анамнеза, осмотр, эндоскопию ЛОР органов, эндоскопическое исследование с оценкой изменений слизистой оболочки пищевода и суточная $\mathrm{pH}$-метрия для верификации ГЭРБ. Исследование вегетативного статуса проводили с помощью тестирования по программе «АнтиБоль 1.06» [20, 21]. В программе тестирования с помощью многомерного вербально-цветового болевого теста заложена оценка уровня болевого поведения по шкале невротизации. Эта шкала позволяет выявить вегетативную дистонию, тревожность, депрессию, ипохондрию. Качественный анализ выбранных ответов по шкале невротизации позволил оценить наличие у больных вегетативной дистонии. Низкий уровень невротизации расценивался в 1-2 балла; средний уровень - 2-4 балла; высокий уровень - 4-6 баллов.

Результаты. У больных 1-й группы уровень невротизации составил $5,098 \pm 0,048$ баллов, что достоверно превысило уровень невротизации у больных 2-й группы равный1,954 $\pm 0,183$ баллов. Для определения наиболее значимых показателей уровня невротизации с точки зрения разделения больных по дифференциальному разделительному значению, был использован ROC-анализ. Диагностической точкой разделения уровня невротизации, при превышении которой возникает необходимость использования дополнительного лечения, была величина 3,4 балла. При достижении этой величины чувствительность метода соответствовала 83 \%, а специфичность - 91 \%. Площадь под ROCкривой (AUC) имела высокое значение 0,914 $\pm 0,024$ (z statistic 7,7 при p<0,0001) при выраженной доверительной вероятности. Вегетативная дистония выявлена у 77 больных, что составило 74,2 \%. Степень выраженности вегетативной 
дистонии не зависела от активности ГЭРБ. При корреляционном анализе показателей ранжированного вегетативного индекса и показателей рН-метрии выявлено отсутствие прямых связей пороговых значений кислотности с выраженностью вегетативной дистонии: $\mathrm{r}=-0,0613 ; \mathrm{p}=0,169$. У больных 1-й группы с патологией ЛОР-органов вегетативная дистония выявлена у 66,8 \% больных. При отсутствии ЛОР патологии у больных 2-й группы вегетативная дистония выявлена у только у 37,8 \% больных.

У 74,8 \% больных 1-й группы выявлена вегетативная дистония в виде асимпатикотонии, у 20,5 \% больных - эйтония, у 4,7 \% - симпатикотонии. Во 2-й группе вегетативная дистония в виде асимпатикотонии у 38,3 \% больных; у 48,1 \% больных - эйтония, симпатикотония - у 13,6 \%.

При проведении корреляционного анализа ранжированных показателей уровня $\mathrm{pH}$ у больных 1-й группы прослеживается прямая статистически значимая связь с показателями вегетативной дистонии: $\mathrm{r}=0,3922 ; \mathrm{p}<0,001$. При корреляционном анализе ранжированных показателей ВИ и уровня рН прямая связь этих показателей отсутствует: $\mathrm{r}=-0,0771 ; \mathrm{p}=0,084$. Эффект взаимного влияния воспалительных изменений в слизистой оболочке верхних дыхательных путей и тонуса ВНС не однозначен [22, 23, 24]. Структурные перестройки, имеющие поначалу компенсаторно-приспособительный характер и являющиеся обратимыми, постепенно закрепляются, переходят в патологические и на основе обратных связей включаются в «порочный круг» заболевания[25]. Функциональное состояние ВНС зависит от длительности воспалительного процесса, а исследование параметров вегетативного индекса может служить критерием оценки и прогнозирования развития воспалительных заболеваний ЛОР органов при ГЭРБ. Таким образом, определение уровня невротизации у больных с ГЭРБ позволяет выявить степень влияния нарушения функционирования ВНС. Пациентам с высоким уровнем невротизации необходимо в алгоритм лечения включать средства и методы, направленные на нормализацию вегетативного статуса. Наличие расстройств функционирования ВНС влияет на патогенез ГЭРБ, определяя её клинические проявления в виде внепищеводной патологии. Поражения слизистой оболочки ЛОР-органов при ГЭРБ в большинстве случаев сочетается с вегетативной дистонией в виде асимпатикотонии и может служить в качестве предиктора развития заболеваний ЛОР-органов. 
1. Морозов С. В., Гибадуллина Л. В., Епанчинцева А. С., Исаков В. А., Свистушкин В. М. Оптимизация диагностики взаимосвязи заболеваний лор органов и ГЭРБ // Экспериментальная и клиническая гастроэнтерология. 2011. № 8. С. 8-18.

2. Скорляков В. В., Дударев И. В., Кещян С. С., Подина М. В. Лечение больных с острыми язвенными гастродуоденальными кровотечениями. В сб: Актуальные проблемы медицины в России и за рубежом. Сборник научтр по итогам междунарнаучпрактконф. 2015. С. 171-174.

3. Кещян С. С. Комплексное лечение острых язвенных гастродуоденальных кровотечений в зависимости от архитектоники сосудистого русла в зоне локализации язвы. Автореф. на соиск...канд. мед наук. Ставрополь, 2012.

4. Чернов В. Н., Скорляков В. В., Маслов А. И. Диагностика и лечение больных с язвенными гастродуоденальными кровотечениями // Вестник эксперим. и клин.хирургии. 2014. № 1. С. 82. Скорляков В. В., Маслов А. И., Бароков Э. М. Тактика лечения больных с острыми гастродуоденальными язвенными кровотечениями // Вестник эксперим. и клин.хирургии. 2010. Т.3 № 1. С. 52-55.

5. Бойко Н. В., Калинкина М. И., Горшкова Г. И. Консервативное лечение хронического тонзиллита // Детская оториноларингология. 2012. № 3. С. 22-24.

6. Бойко Н. В. Головокружение в практике врача-терапевта // Лечащий врач. 2010. № 4. С. 86. Бойко Н. В., Шатохин Ю. В. Патогенез носовых кровотечений у больных с артериальной гипертензией // Вестник оторинолар. 2015. Т. 80. № 5. С. 41-45.

7. Стагниева И.В., Гукасян Е.Л., Сагакянц А.Б.Нарушение нейроиммунной реактивности у больных риносинуситом. Российская ринология. 2015. Т. 23. № 1. С. 25-28.

8. Волков А.Г., Стагниева И.В.Головная боль в области лба с точки зрения оториноларинголога. Российская ринология. 2007. № 4. С. 29-34.

9. Бабиев В. Ф. Прогнозирование и контроль течения острых хирургических заболеваний, осложненных перитонитом. Автореф. на соиск...канд. мед наук. Ростов-на-Дону, 1996.

10. Чернов В. Н., Скорляков В. В., Кещян С. С. Терапия и хирургия осложненных форм язвенной болезни // Рос.журнал гастроэнтер., гепатол., колопроктол. 2010. Т. 20 № 5. С. 40.

11. Чернов В. Н., Скорляков В. В., Баев О. В. Лечение перфоративной язвы гастродуоденальной зоны. Вестник хирургической гастроэнтерологии. 2006. № 1. С. 79.

12. Бойко Н. В., Колмакова Т. С. Исследование биогенных аминов у больных с носовыми кровотечениями на фоне вегетативной дисфункции // FoliaOtorhinolar. etPatholRes. 2015. T 21. № 2. C. 27-29.

13. Бойко Н. В., Колмакова Т. С., Быкова В. В. Биохимические показатели компенсации постгеморрагической анемии у больных с носовыми кровотечениями // Вестник оторинолар. 2010. № 4. С. 13-16.

14. Стагниева И. В. Вегетативная дисфункция в проявлении прозопалгий у больных с риносинуситами // Медицинский вестник Юга России. 2012. № 2. С. 67-69.

15. Стагниева И. В. Роль субстанции Р в патогенезе лицевой боли при риносинусите // Российская ринология. 2015. Т. 23. № 1. С. 33-35.

16. Стагниева И. В., Симбирцев А. С. Значение цитокинового профиля в проявлении болевого симптома при риносинусите // Цитокины и воспаление. 2015. Т. 14. № 4. С. 29-34. 
17. Стагниева И. В. Лечение лицевой боли при риносинусите // Медицинский вестник Юга России. 2015. № 1. С. 82-85.

18. Стагниева И.В., Симбирцев А.С.Роль цитокинов в патогенезе лицевой боли при риносинусите // Медицинская иммунология. 2015. Т. 17. № S. С. 319.

19. Стагниева И. В. Иммунотропная терапия в лечении рецидивирующего риносинусита // В мире научных открытий. 2017. Т. 9. № 1. С. 56-65.

20. Стагниева И. В., Бойко Н. В. Головная и лицевая боль при риносинусите //Медицинский вестник Юга России. 2014. № 3. С. 55-59.

21. Быкова В.В., Залесский А.Ю. Редкая причина рецидивирующего носового кровотечения. Российская ринология. 2015. Т. 23. № 1. С. 52-54.

22. Волков А.Г., Гюсан А.О., Боджоков А.Р., Стагниева И.В., Хохлачев С.М., Узденова Р.Х., Давыдова Л.С.Анализ орбитальных и внутречерепных осложнений синуситов по некоторым стационарам Северного Кавказа// Российская оториноларингология. 2008. № 4. C. 57-61.

23. Бойко Н.В., Стагниева И.В.Дифференциальная диагностика лицевых болей // Российская ринология. 2012. Т. 20. № 4. С. 39-41.

24. Стагниева И.В., Бойко Н.В.Головная и лицевая боль при риносинусите // Медицинский вестник Юга России. 2014. № 3. С. 55-59.

25. Стагниева И.В., Сагакянц А.Б.Лицевая боль как проявление заболеваний носа и околоносовых пазух // Российский журнал боли. 2014. № 3-4. С. 40-44. 